\title{
The relationship between anti-Ro autoantibody positivity and the frequency of neurological involvement in Sjögren's syndrome
}

\section{Sjögren sendromunda nörolojik tutulum sıklığl ille antí- Ro otoantikor pozitifliği arasındaki ilişki}

\author{
Mehmet Emin Derin ${ }^{1}$, Ali Şahin ${ }^{2}$, Burhanettin Çiğgem ${ }^{3}$, Ayşe Camcı Urhan ${ }^{1}$, Derya Seven ${ }^{4}$, \\ Mehtap Şahin ${ }^{5}$
}

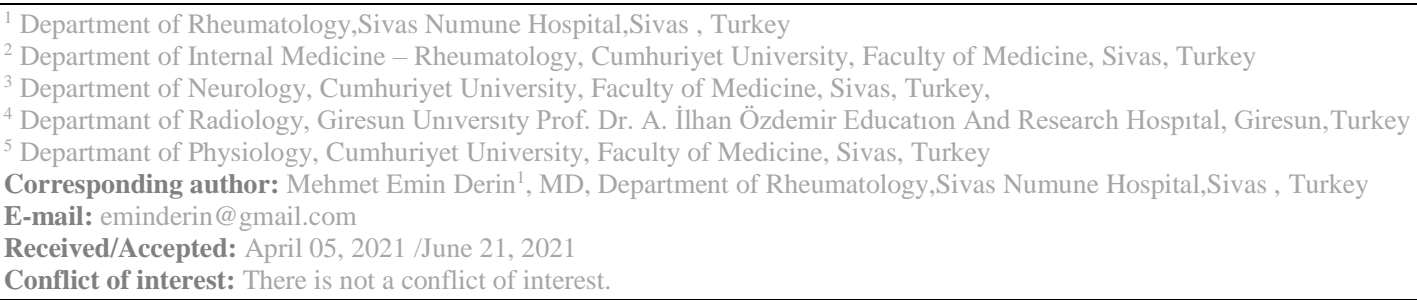

\section{SUMMARY}

Objective: The aim of this study is to investigate the frequency of neurological and other involvement patterns of the Primary Sjögren's syndrome (pSS).

Method: Between June 2015 and January 2017, sixty SJS patients who were being followed up at Cumhuriyet University Medical Faculty Rheumatology-Internal Medicine Department were evaluated in the study. Their clinical complaints, glandular and extra-glandular findings, age, sex, other epidemiological data, Antinuclear antibody (ANA), Rheumatoid factor (RF), anti-Ro/La, Complemans (C3, C4), IgG, IgA, IgM levels were recorded.

Results: The mean age of the patients was $47.7 \pm 1.3$ years, and the mean age at diagnosis was $47.1 \pm 1.6$ years. Of the SS patients, fifty-nine (98.3\%) were female and one $(1.7 \%)$ was male. The frequencies of the clinical symptoms were as follows: arthralgia in $81.7 \%$, arthritis in $46.7 \%$, and biopsy-proven vasculitic lesions in $5 \%$. The frequencies of the neurological symptoms were as follows: headache in $68.75 \%$, localized numbness in $6.25 \%$, seizure in $6.25 \%$, paresthesia in $12.5 \%$, and loss of function in $6.25 \%$ (Figure 1). The total frequency of neurological involvement was $26.7 \%$ in $\mathrm{SjS}$ patients. Peripheral nervous system involvement was seen in $8.3 \%$. The findings of the magnetic resonance imaging of the patients with neurological involvement were non-specific gliotic lesions in $25 \%$, periventricular lesions in $31.25 \%$, parenchymal vasculitic lesions in $31.25 \%$, and multiple sclerosis-like plaques in $12.5 \%$. Anti-Ro positivity was found in $58.3 \%$, RF in $53.3 \%$, ANA in $78.3 \%$, and low complement levels in $15 \%$. However, anti-Ro positivity was lower in patients with neurological involvement than in patients without neurological involvement $(\mathrm{p}=0.025)$.

Conclusions: Neurological involvement should be kept in mind in patients diagnosed with SS. It can be seen more commonly than expected. In addition, further studies are needed to evaluate the mysterious role of antiRo autoantibody in SS patients with neurological involvement.

Keywords: Sjögren's syndrome, neurological involvement, frequency

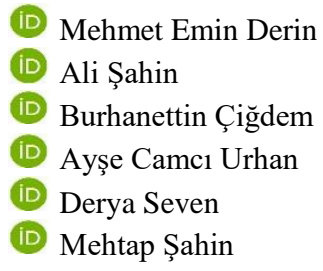

ORCID IDs of the authors: M.E.D. 0000-0002-8830-8848 A.Ş. 0000-0002-6953-4276 B.C. 0000-0003-4941-9497 A.C.U. 0000-0001-5119-2864 D.S. 0000-0002-7074-1256 M.Ș. 0000-0003-4518-6489 
ÖZET

Amaç: Bu çalı̧̧manın amacı, Primer Sjögren sendromunun (pSS) nörolojik ve diğer tutulum paternlerini sıklığını ve otoantikorlar ile ilişkisini araştırmaktır.

Yöntem: Haziran 2015-Ocak 2017 tarihleri arasında Cumhuriyet Üniversitesi Tıp Fakültesi Romatoloji-İ̧ Hastalıkları Anabilim Dalı'nda izlenen 60 pSS hastası çalışmada değerlendirildi. Klinik şikayetleri, glandüler ve ekstra glandüler bulguları, yaş, cinsiyet, diğer epidemiyolojik veriler, antinükleer antikor (ANA), Romatoid faktör (RF), anti-Ro / La, kompleman düzeyleri (C3, C4), Immunglobulin ( $\operatorname{IgG}$, $\operatorname{IgA}$, $\operatorname{IgM})$ düzeyleri kaydedildi.

Bulgular: Hastaların ortalama yaşı $47.7 \pm 1.3$ yıl ve ortalama tanı yaşı $47.1 \pm 1.6$ yıldı. pSS hastalarının elli dokuzu (\% 98.3) kadın, biri (\% 1.7) erkekti. Klinik semptomların sıklığı \% 81.7 artralji, \% 46.7 artrit ve $\% 5$ biyopsi ile kanıtlanmış vaskülitik lezyonlardı. Nörolojik semptomların sıklığı ise \% 68.75 baş ağrısı, $\% 6.25$ lokalize uyuşma, \% 6.25 nöbet, \% 12.5 parestezi ve \% 6.25 fonksiyon kaybı şeklinde saptandı. SS hastalarında toplam nörolojik tutulum sıklığı \% 26.7 idi. Periferik sinir sistemi tutulumu ise \% 8.3 oranında görüldü. Nörolojik tutulumu olan hastaların manyetik rezonans görüntüleme bulguları: \% 25 non-spesifik gliotik lezyonlar, \% 31.25 periventriküler lezyonlar, \% 31.25 parankimal vaskülitik lezyonlar ve \% 12.5 multipl skleroz benzeri plaklardı. Anti-Ro pozitifliği \% 58.3, RF\% 53.3, ANA\% 78.3 ve düşük kompleman seviyeleri \% 15 olarak bulundu. Ancak anti-Ro pozitifliği nörolojik tutulumu olan hastalarda nörolojik tutulumu olmayan hastalara göre daha düşüktü $(\mathrm{p}=0,025)$.

Sonuç: pSS tanısı alan hastalarda nörolojik tutulum akılda tutulmalıdır. Beklenenden daha sık görülebilir. Ek olarak, nörolojik tutulumu olan SS hastalarında anti-Ro otoantikorunun rolünü değerlendirmek için daha fazla çalışmaya ihtiyaç vardir.

Anahtar sözcükler: Sjögren sendromu, Manyetik rezonans, Nörolojik tutulum, S1klık

\section{INTRODUCTION}

Sjögren's syndrome is an autoimmune rheumatic disease that affects multiple glandular and extraglandular tissues ${ }^{1}$. Autoantibodies (mainly antiRo-SS-A and anti-La-SS-B) contribute to playing roles in its clinical pictures ${ }^{2}$. Central and peripheral nervous system involvement may be seen as different sign, symptoms and varying its frequencies ${ }^{2}$. It is nine times more frequent in women and is usually diagnosed between 40 to 50 years of age and has a prevalence ranging from 0.05 to $0.7 \%^{3-5}$. There is no consensus on the etiology of SS, but it is known to be multifactorial 6.

Sjögren's syndrome with no underlying disease is known as the primary SS (pSS) whereas it is called the secondary SS when it is accompanied by connective tissue disorders including systemic lupus erythematosus, rheumatoid arthritis or scleroderma ${ }^{7}$. ACR (American Collage of Rheumatology) or the American-European Consensus Group's criteria are based on in its diagnosis.

Although exocrine glands involvement is prominent, dry skin, palpable or non-palpable purpuras due to small-vessel vasculopathy, livedo reticularis, wide-range skin involvement from erythematous skin lesions to panniculitis, polyarthralgia with prominent small joint involvement or polyarthritis depending on the component of the accompanying connective tissue disease (generally in about 30\%), pulmonary involvement in about 9 to $12 \%$ (cough, airway dryness, recurrent bronchitis and small airway obstruction), primary biliary cirrhosis and increased frequency of autoimmune hepatitis, renal involvement including tubulointerstitial nephritis, renal tubular acidosis or glomerulonephritis, gynecologic involvement including dyspareunia and vaginal dryness, vasculitic involvement affecting small vessels in about $10 \%$ of the cases, and wide range of neurological involvements from asymptomatic skill lesions to sensory and motor neuropathy, headache, neuromyelitis optica and multiple sclerosis can be seen ${ }^{8-9}$.

The prevalence of neurological manifestations may vary from 10 to $60 \%$, with this wide range being due to the differences in the studied populations and in neuropathy definitions and methodologies used in studies 10,11 . Both the central nervous system and the peripheral nervous system may be involved. While the pathogenesis of the neurological symptoms is still clear, there are hypotheses suggesting direct infiltration of central nervous system cells by mononuclear cells or secondary involvement due to the vasculopathy. Vascular involvement may be associated with presence of anti-neural antibodies and anti-Ro antibodies ${ }^{10,13}$. The most common manifestation in pSS is sensorial neuropathy but multiple neuropathies may also be seen. Nerve conduction investigations yield normal results in pure sensorial neuropathy, and symptoms such as numbness, burning sensation and hyperesthesia are observed. Although not as common as the mentioned mild involvements, peripheral nervous system involvement including demyelination, function 
loss and ataxia due to neuron involvement and mononeuritis multiplex can be seen ${ }^{14}$.

The objective of the present study is to investigate the patterns of neurological involvement in particular as well as the patterns of other clinical involvements, magnetic resonance findings, the role of autoantibody positivity, and their correlations in patients with primary Sjögren's syndrome who were diagnosed and being followed up in our clinic.

\section{MATERIAL AND METHODS}

The study included 60 patients aged 20 to 70 years who were diagnosed with primary Sjögren's syndrome according to the ACR criteria and being followed up at Sivas Cumhuriyet University, Internal Medicine Department, Rheumatology Clinic between June 2015 and June 2016. Conditions which can be the cause of secondary Sjögren's syndrome including systemic lupus erythematosus, scleroderma or rheumatoid arthritis were excluded. Patients with hepatitis (especially HBV, HCV), HIV, sarcoidosis, and underlying infiltrative conditions as well as those with history of head-neck radiotherapy, drug usage (antihypertensive, antidepressants, etc.) were excluded from the study.

For each patient, presence of dry mouth and dry eye, positive Schirmer's I test, arthritis, arthralgia, Chisholm score in salivary gland biopsy, skin involvement, neurologic symptoms, peripheral neuropathy findings, central nervous system involvement findings, findings in magnetic resonance imaging, findings indicating pulmonary or hepatic involvement, proteinuria and creatinine levels, complement, cardiolipin Ig $\mathrm{G}$ and Ig $\mathrm{M}$, ANA, RF, Anti-CCP, Anti-dsDNA, anti Ro, anti La, Ro-52, centromere positivity and cytopenia with CRP sedimentation rate were questioned.

Neurologic symptoms were grouped as headache, localized numbness, seizures, paresthesia and loss of function. Findings of neuropathy demonstrated with EMG were considered as peripheral nervous system involvement. Patients with lesions detected with MRI in addition to those with central nervous system involvement, clinical examination findings and symptoms, were included. MRI findings were grouped as nonspecific gliotic foci, periventricular lesions, parenchymal vasculitic lesions and multiple sclerosis (MS)-like plaques. Patients with peripheral neuropathy in EMG and those with radiological findings in addition to neurological symptoms were considered to have neurological involvement after a consultation with a neurologists.
Pulmonary involvement was determined based on abnormalities found in lung tomography taken in patients who had cough, shortness of breath and functional restriction. Findings of involvement were studied under 4 groups as interstitial lung disease, non-specific ground glass densities, nodule growth and nonspecific changes (mild fibrosis, minimal ground glass). Presence of autoimmune hepatitis and primary biliary cirrhosis were considered as hepatic involvement.

Patients with significant proteinuria or biopsyproven glomerulonephritis were considered to have renal involvement. With respect to skin involvement, patients were grouped as those with skin dryness, rash (palpable purpura or erythematous lesions) and biopsy-proven vasculitis.

Levels above age-appropriate limit for sedimentation and above $5 \mathrm{mg} / \mathrm{dl}$ for CRP were considered significant. Correlations between sedimentation and CRP levels, irrespective of their being high or low, and organ involvement were investigated.

ANA and anti-ds DNA were studied using fluorescence and ELISA methods. Positivity was concluded for titers above 1/160 for ANA and for values above 20 for anti CCP and RF. For proteinuria, values above $500 \mathrm{mg} / \mathrm{dl} /$ day were considered as significant proteinuria. Patients with white blood cells below $4000 \mathrm{u} / \mathrm{ml}$ were considered to have cytopenia.

Our study was initiated after receiving the approval (decision no 2016-05/34) of the Ethics Board of the Medical Faculty of Cumhuriyet University and was conducted in accordance with the requirements of the Declaration of Helsinki.

\section{Statistical analysis}

For statistical analysis, the non-parametric independent sample test was used to compare the quantitative data of the patients with and without neurological involvement because the standard deviation was more than half of the average value. Chi-square test was used for inter-group comparison of categorical data. Data were analyzed using SPSS 22.0 with statistical significance set at $\mathrm{p}<0.05$.

\section{RESULTS}

Sixty patients were included in the study. Patient information, clinical and laboratory findings are presented in Table 1, as 2 separate groups with and without central nervous system involvement. Patients' median age was 47 (22 -77) years and their median age at diagnosis was also 47 (22-77) 
years. The two groups did not differ significantly with respect to age at diagnosis.

Fifty-nine (98.3\%) of the patients were women and one was men $(1.7 \%)$. Sixteen of the patients (26.7\%) had central nervous system involvement. Forty-four (73.3\%) had no CNS involvement. All patients (100\%) with CNS involvement were women. Clinical symptoms of arthralgia were observed in 49 patients $(81.7 \%)$ and arthritis in 28 patients $(46.7 \%)$. The two groups did not differ significantly with respect to articular findings $(p>0.05)$. All patients $(100 \%)$ had oral and ocular symptoms. Dermatological findings included dry skin in $30(50 \%)$ patients and vasculitis as evidenced by biopsy in $3(5 \%)$ patients.

All patients with vasculitis were in the group with CNS involvement. Four (6.6\%) patients with CNS involvement had pulmonary involvement and 12 (20\%) patients without CNS involvement had pulmonary involvement. Pulmonary involvement patterns included ground glass appearance in 5 $(31.25 \%)$ patients, nodular growth in $6(37.75 \%)$ patients and non-specific findings in $5(31.25 \%)$ patients. The two groups did not differ significantly with respect to pulmonary involvement ( $p>0.05)$.

Table 1: Information and laboratory findings of the patients included in the study

\begin{tabular}{|c|c|c|c|c|}
\hline & $\begin{array}{l}\text { All patients } \\
(\mathbf{n}: 60)\end{array}$ & $\begin{array}{l}\text { Patients with CNS } \\
\text { involvement(n:16) }\end{array}$ & $\begin{array}{l}\text { Patients without CNS } \\
\text { involvement (n:44) }\end{array}$ & $p$ value \\
\hline $\begin{array}{l}\text { Female to male } \\
\text { ratio }\end{array}$ & $59 / 1$ & $16 / 0$ & $43 / 1$ & \\
\hline Age, mean (SD) & $47,7( \pm 13,2)$ & $44,6( \pm 11,4)$ & $48,8( \pm 13,8)$ & 0,28 \\
\hline $\begin{array}{l}\text { Age at diagnosis, } \\
\text { mean }(S D)\end{array}$ & $47,18( \pm 13)$ & $45,44( \pm 11,03)$ & $47,8( \pm 13,8)$ & 0,54 \\
\hline Ocular symptoms & 60 & 16 & 44 & 1 \\
\hline Oral symptoms & 60 & 16 & 44 & 1 \\
\hline Arthritis & 28 & 7 & 21 & 0,785 \\
\hline Arthralgia & 49 & 13 & 36 & 0,96 \\
\hline Vasculitis & 3 & 3 & 0 & 0,005 \\
\hline $\begin{array}{l}\text { Pulmonary } \\
\text { involvement }\end{array}$ & 16 & 4 & 12 & 0,307 \\
\hline Renal involvement & 6 & 2 & 4 & 0,697 \\
\hline $\begin{array}{l}\text { Peripheral nerve } \\
\text { involvement }\end{array}$ & 5 & 5 & 0 & $\mathbf{0 , 0}$ \\
\hline $\begin{array}{l}\text { Anti-SS-A } \\
\text { presence }\end{array}$ & 25 & 5 & 20 & 0,682 \\
\hline $\begin{array}{l}\text { Anti-SS-B } \\
\text { presence }\end{array}$ & 13 & 5 & 8 & 0,129 \\
\hline$R F$ positivity & 32 & 7 & 25 & 0,37 \\
\hline ANA positivity & 47 & 10 & 37 & 0,354 \\
\hline Low complement & 9 & 0 & 9 & 0.05 \\
\hline Anti Ro 52 & 35 & 5 & 30 & 0,042 \\
\hline Elevated Ig $G$ & 13 & 1 & 12 & 0,08 \\
\hline AFAS ab presence & 8 & 4 & 4 & 0,08 \\
\hline
\end{tabular}




\section{Central Nervous System Involvement}

Neurological involvement was observed in 16 $(26.7 \%)$ patients. Five $(8.3 \%)$ patients had concomitant peripheral nerve system involvement.
Neurological symptoms included headache in 11 $(68.75 \%)$ patients, paresthesia in $2(12.5 \%)$ patients, seizure history in $1(6.25 \%)$ patient, localized numbness in $1(6.25 \%)$ patient, and loss of function in $1(6.25 \%)$ patient (Figure 1).

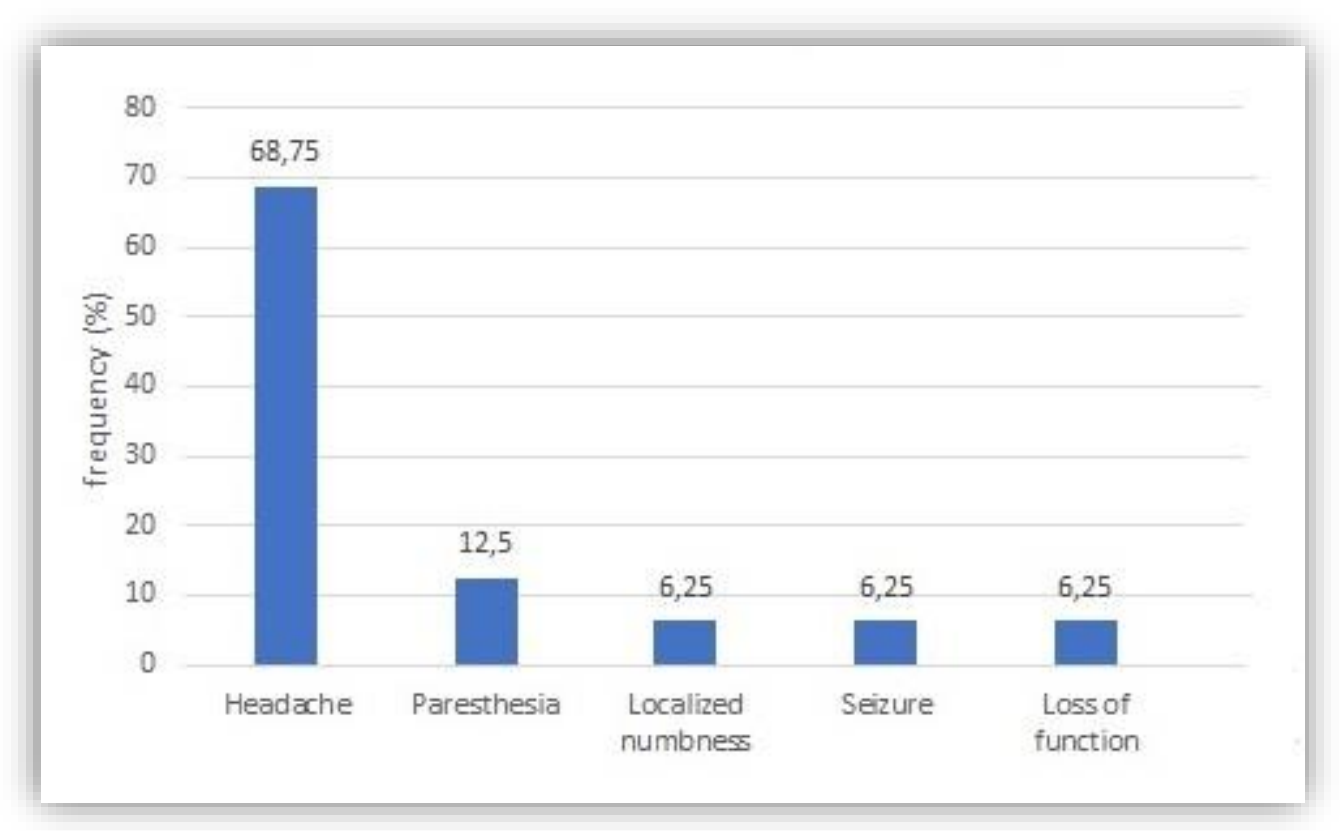

Figure 1: CNS involvement patterns of the patients with Sjögren's Syndrom

Neurological MR imaging results included involvement patterns of non-specific gliotic lesions in $4(25 \%)$ patients, periventricular lesions in 5 $(31.25 \%)$ patients, parenchymal vasculitic lesions in $5(31.25 \%)$ patients and MS-like plaques in 2 (12.5\%) patients.

Eleven $(68.75 \%)$ patients in the group with CNS involvement had headache. These patients also had abnormal MRI findings, which included parenchymal vasculitic lesions in 4 (36.3\%) patients, non-specific gliotic lesions in 4 (25\%) patients, and periventricular white matter lesions in $3(27.4 \%)$ patients. All patients had been diagnosed with migraine for headache. Their headaches were controlled with anti-migraine therapy.

Two patients $(12.5 \%)$ had paresthesia. These patients were 25 and 39 years old and both had paresthesia in the lower extremities. With cranial MRI, one patient had parenchymal vasculitic lesions, and the other had multiple sclerosis-like plaque. Electromyography (EMG) was performed and demonstrated neuropathy. These patients were concluded to have concomitant peripheral nervous system involvement.
One patients $(6.25 \%)$ had seizure history. This patient was a 25-year-old female. She was diagnosed with epilepsy approximately 2 years before the onset of sicca symptoms. Cranial MRI of the patient demonstrated periventricular white matter lesions.

One patient $(6.25 \%)$ had localized numbness. This patient was a 58 -year-old female. The onset of her facial numbness was approximately 2 years before the sicca symptoms. Cranial MRI of this patient also involved periventricular white matter lesions.

One patient $(6.25 \%)$ had loss of function and loss of strength in the upper right extremities. With MSlike plaques in MRI, this patient was a 34-year-old female. She experienced loss of strength approximately 1 year before the onset of sicca symptoms. EMG was performed for this patients and demonstrated neuropathy. The finding was interpreted as co-existing peripheral nervous system involvement. 


\section{Results of antibody tests and laboratory analyses}

Forty-seven patients (78.3\%) had ANA positivity, $32(53.3 \%)$ had RF elevation, 26 (43.3\%) had SSA (anti-Ro) positivity, and 13 (38.3\%) had SS-B (anti-La) positivity. No significant difference was noted between the two groups.

Nine patients (15\%) had low complement levels. None of these 9 patients had neurological involvement $(\mathrm{p}<0.05)$.

Five patients with CNS involvement were positive for anti-Ro52, while 30 patients without CNS involvement were positive for anti-Ro $52(\mathrm{p}<0.05)$.

Anti Ro positivity was significantly less frequent in the group with neurological involvement compared to the group without neurological involvement $(\mathrm{p}=\mathbf{0 . 0 2 5})$

Mean serum CRP was $12.1 \mathrm{mg} / \mathrm{dl}$ in the group with neurological involvement compared to $9.89 \mathrm{~g} / \mathrm{dl}$ in the group without neurological involvement. No significant differences were observed with respect to organ involvements $(\mathrm{p}=0.32)$

Cytopenia was observed in $3(59 \%)$ patients with CNS involvement and in $6(10 \%)$ patients without CNS involvement. No significant differences were observed $(\mathrm{p}=0.62)$.

\section{DISCUSSION}

CNS involvement in primary Sjögren's syndrome involves a very heterogeneous and wide spectrum. According to the literature, the prevalence of CNS involvement ranges between 0 to $19 \%$. RamosCasals et al. demonstrated CNS involvement in 2\% of 1010 patients ${ }^{15}$ compared to Massara et al. who demonstrated CNS involvement in $5.8 \%$ of 424 patients in an Italian cohort ${ }^{16}$, Teixeira et al. who demonstrated CNS involvement in $12.3 \%$ of 89 patients ${ }^{17}$, and Moreira et al. who demonstrated CNS involvement in $15 \%$ of 93 patients. CNS involvement was $26.7 \%$ in our study. This was higher than the prevalence of involvement shown in other studies. All $(100 \%)$ of the patients with CNS involvement were women.

Oral and ocular findings were similar between patients with and without CNS involvement and the proportion of patients with involvement was $100 \%$. Teixare et al. found significantly high frequency of pulmonary involvement in the patient group with CNS involvement ${ }^{17}$, whereas the difference was not significant in our study. The same study demonstrated that $46 \%$ of the patients with neurological involvement had no sicca symptoms at the time of onset of the symptoms ${ }^{17}$. In our study, neurological symptoms was present before sicca symptoms in $60 \%$ of the cases. This demonstrates that a careful systemic examination should be performed and rheumatologic history should be taken especially in patients presenting with sensorial or motor neuropathy, acute chronic myelopathy or multifocal CNS signs.

Peripheral nervous system involvement has been reported generally as sensory neuropathy ${ }^{19}$. Our study mostly demonstrated dysesthesia and local burning sensation in the legs. CNS involvement is generally reported in the literature as focal involvement. Only in the cohort studied by Massara et al. ${ }^{16}$, diffuse neurological involvement such as subacute encephalopathy was noted more frequently.

Laboratory investigations demonstrated significantly higher degrees of complement deficiency and Anti-Ro 52 positivity in patients with CNS involvement compared to those without CNS involvement. This difference was not observed in previous studies. While anti-Ro-52 positivity was lower in patients with CNS involvement, it is not an antibody that can be used in CNS involvement as anti-Ro-52 positivity is also seen in Sjögren's CNS involvement.

Sjögren's Syndrome can be confused with other neurological conditions because it has a very wide spectrum of neurological involvement patterns. Neuromyelitis optica (NMO) was observed in some cohorts ${ }^{20}$. This co-existence of conditions was not observed in our patients. Anti-AQP4 antibodies and CSF analysis can be helpful in establishing a diagnosis in NMO.

MS-like plaques can be a pattern of CNS involvement. These plaques were observed in 5\% of the patients with CNS involvement in the cohort studied by Massara et al. ${ }^{16}$. Our study demonstrated the same 5\% ratio. MS and Sjögren's CNS involvement are very challenging to differentiate since similar autoantibody positivities can be seen in MS. In addition to detailed history and physical examination, findings of Sjögren's syndrome need to be investigated thoroughly.

MRI findings can also be diverse. No MRI finding is specific to this condition. Factors such as age, sex, atherosclerosis, diabetes may result in particular impact. Therefore, clinical symptoms and findings should be combined with MRIs by experienced radiologists.

\section{CONCLUSION}

The prevalence of CNS involvement in Sjögren's syndrome is not clear. We wanted to determine the frequency of CNS involvement and clinical and laboratory characteristics in patients in our clinic. 
We believe that patients with findings of CNS involvement warrant detailed investigations as these findings may precede sicca symptoms. Moreover, in the absence of specific diagnostic methods, such patients should be evaluated and treated through a multidisciplinary approach. Larger multicenter studies are needed to establish the pathogenesis and prevalence of CNS involvement in Sjögren's syndrome.

Acknowledgements: We would like to thank to Ziynet Çınar, M.D. for her statistical analysis.

\section{REFERENCES}

1. Mavragani CP, Moutsopoulos HM. Sjogren syndrome. CMAJ 2014 Oct 21;186(15):E57986. doi: 10.1503/cmaj.122037. Epub 2014 Feb 24.

2. Soliotis FC, Mavragani CP, Moutsopoulos HM. Central nervous system involvement in Sjogren's syndrome. Ann Rheum Dis 2004 Jun;63(6):616-20.

3. Kassan SS, Moutsopoulos HM (2004) Clinical manifestations and early diagnosis of Sjögren syndrome. Archives of Internal Medicine 164(12): 1275-84

4. Bayetto K, Logan RM (2010) Sjögren's syndrome: a review of aetiology, pathogenesis, diagnosis and management. Australian Dental Journal (Suppl. 1): 39-47

5. Mavragani CP, Moutsopoulos HM (2010) The geoepidemiology of Sjögren's syndrome. Autoimmunity Reviews 9(5): A305-10

6. Von Bultzinglowen I, Sollecito T, Fox P, et al. Salivary dysfunction associated with systemic diseases: systematic review and clinical management recommendations. Oral Surg Oral Med Oral Pathol Oral Radiol Endod 2007;103:S57.e1-15.

7. Ramos-Casals M, Tzioufas A, Font J. Primary Sjögren's syndrome: new clinical and therapeutic concepts. Ann Rheum Dis2005;64:347-354.

8. Al-Hasimi I, Khuder S, Haghighat N, Zipp M. Frequency and predictive value of the clinical manifestations in Sjögren's syndrome. J Oral Pathol Med 2001;301-306.

9. Skopouli F, Dafni U, Ioannidis J, Moutsopoulos H. Clinical evolution, and morbidity and mortality of primary Sjögren's syndrome. Semin Arthritis Rheum 2000;29:296-304.

10. Chai J, Logigian E. Neurological manifestations of primary Sjogren's syndrome. Current Opinion in Neurology 2010, 23:509-511.
11. Vitali C, Bombardieri S, Jonsson R, et al. Classification criteria for Sjogren's syndrome: a revised version of the European criteria proposed by the American-European Consensus Group. Ann Rheum Dis 2002; 61:554-558

12. Bamford J, Sandercock P, Dennis M, et al A prospective study of acute cerebrovascular disease in the community. J Neurol Neurosurg Psychiatry. 1988;51:1373-1380 5. Bamford JM Sandercock PAG et al. Letter to the Editor:

13. Gono T, Kawaguchi Y, Katsumata $\mathrm{Y}$ et al. Clinical manifestations of neurological involvement in primary Sjögren's syndrome. Clin Rheumatol 2011; 30:485-490.

14. Delalande S, de Seze J, Fauchalis AL, Hachulla E, Stojkovic T, Ferriby D, et al. Neurologic manifestations in primary Sjogren syndrome: a study of 82 patients. Medicine (Baltimore) 2004; 83(5):280-91

15. Ramos-Casals M, Solans R, Rosas $\mathrm{J}$ et al. Primary Sjögren syndrome in Spain: clinical and immunologic expression in 1010 patients. ; GEMESS Study Group. Medicine (Baltimore). $2008 \quad$ Jul;87(4):210-9. doi: 10.1097/MD.0b013e318181e6af.

16. Massara A, Bonazza S, Castellino $G$ et al Central nervous system involvement in Sjögren's syndrome: unusual, but not unremarkable--clinical, serological characteristics and outcomes in a large cohort of Italian patients.. Rheumatology (Oxford). 2010 Aug;49(8):1540-9.

17. Teixeira F, Moreira I, Silva AM,et al. Neurological involvement in Primary Sjögren Syndrome. Acta Reumatol Port. 2013 JanMar;38(1):29-36.

18. Moreira I, Teixeira F, Martins Silva A et al Frequent involvement of central nervous system in primary Sjögren syndrome. Rheumatol Int. 2015 Feb;35(2):289-94. doi: 10.1007/s00296014-3097-9.

19. Hoitsma E, Reulen JP, de Baets M et al . Small fiber neuropathy: a common and important clinical disorder. J Neurol Sci. 2004 Dec 15;227(1):119-30. Review.

20. Wingerchuk DM, Lennon VA, Lucchinetti CF, Pittock SJ, Weinshenker BG. The spectrum of neuromyelitis optica.Lancet Neurol. 2007 Sep;6(9):805-15. Review. 